\title{
Konjungsi Wacana Bahasa Indonesia pada Wacana Media Tulis (Online), Buku Teks (Pelajaran), dan Artikel Ilmiah
}

\author{
Febri Amalia $\bowtie$, Bambang Hartono, Santi Pratiwi Tri Utami \\ Jurusan Bahasa dan Sastra Indonesia, Fakultas Bahasa dan Seni, Universitas Negeri Semarang, \\ Indonesia
}

\section{Info Artikel}

Sejarah Artikel:

Diterima Agustus 2017

Disetujui Desember 2017

Dipublikasikan Maret

2018

\section{Keywords:}

conjunctions, between sentences, between pharagrap

\begin{abstract}
Abstrak
Penelitian ini bertujuan mengidentifikasi wujud konjungsi wacana antarkalimat dan antarparagraf yang terdapat pada wacana media tulis (online), buku teks (pelajaran), dan artikel ilmiah. Pendekatan yang digunakan pada penelitian ini adalah pendekatan teoretis dan pendekatan metodologis. Pendekatan teoretis yang digunakan berupa teori analisis wacana, sedangkan pendekatan metodologis yang digunakan berupa deskriptif kualitatif. Data penelitian ini berupa penggalan wacana tajuk rencana online Suara Merdeka.com edisi bulan Juni 2016 sampai dengan Juli 2016, buku ajar BSE Bahasa dan Sastra Indonesia SMP sampai dengan SMA terbitan Pusat Perbukuan Departemen Pendidikan Nasional, dan artikel ilmiah populer yang diakses dalam link https://parapenuliskreatif.wordpres.com/category/artikel-ilmiahpopuler/page/4/. Metode pengumpulan data yang digunakan adalah metode simak, kemudian dilanjutkan dengan teknik catat. Metode analisis data yang digunakan adalah metode agih. Metode penyajian hasil analisis data yang digunakan dalam penelitian ini adalah penyajian informal. Berdasarkan data penelitian, ditemukan 234 data wujud konjungsi wacana antarkalimat dan antarparagraf. Adapun konjungsi wacana terdiri atas 8 bentuk konjungsi kohesi antarkalimat koordinatif serta 6 bentuk konjungsi kohesi antarkalimat subordinatif. Jika konjungsi kohesi antarparagraf koordinatif ada 4 bentuk dan kohesi konjungsi antarparagraf subordinatif ada 5 bentuk.
\end{abstract}

\begin{abstract}
This study aims to identify the form of conjunctions discourse between sentence and between paraghrap contained on media discourse write (online), textbooks (lessons), and scientific articles. The approach used in this study is the theoretical approaches and methodological approaches. Theoretical approaches used in the form of discourse analysis theory, whereas the methodological approaches used in the form of qualitative descriptive. This research data in the form of a fragment of discourse editorial Merdeka.com Vote online edition in June 2016 until July 2016, textbook BSE Indonesia Language and Literature junior high school until the issue of Central Book Ministry of National Education, and popular scientific articles that are accessed in the link https://parapenuliskreatif.wordpres.com/categorv/artikel-ilmiahpopuler/page/4/. Data collection method used is the method see, then proceed with the techniques noted. The data analysis method agih. Method of presenting the results of data analysis used in this study is an informal presentation. Based on research data found 234 data discourse form conjunctions between sentences and between paragraphs. The conjunctions of discourse consists of 8 form coordinative conjunctions cohesion between sentences, and 6 forms of cohesion between sentences subordinating
\end{abstract}


Febri Amalia dkk. / Jurnal Sastra Indonesia 7 (1) (2018)

conjunctions. If the coordinating conjunctions cohesion between existing paragraphs 4 form and cohesion between paragraphs subordinating conjunctions there are 5 form.

(C) 2018 Universitas Negeri Semarang

Alamat korespondensi:

ISSN 2252-6315

Gedung B1 Lantai 1 FBS Unnes

Kampus Sekaran, Gunungpati, Semarang, 50229

E-mail: piscesfebry@yahoo.co.id 


\section{PENDAHULUAN}

Bahasa merupakan hal penting yang perlu dipelajari karena bahasa mempunyai fungsi dan peranan yang besar dalam kehidupan manusia. Fungsi bahasa yang utama yaitu sebagai alat komunikasi yang digunakan oleh setiap manusia dalam kehidupannya mulai dari bangun tidur, melakukan aktivitas, hingga akan tidur lagi.

Secara garis besar, dalam berkomunikasi manusia menggunakan media yang berbedabeda. Sarana komunikasi dibedakan menjadi dua macam, yaitu sarana lisan dan tulis. Media lisan yaitu media tanpa perantara, sedangkan media tulis yaitu media yang menggunakan perantara, salah satu contoh media tulis adalah wacana.

Kesatuan bahasa yang diucapkan atau tertulis panjang atau pendek, itulah yang dinamakan teks atau wacana. Wacana merupakan satuan bahasa yang lengkap sehingga dalam hierarki gramatikal merupakan satuan gramatikal tertinggi atau terbesar. Pendapat lain mengenai wacana dinyatakan oleh Kridalaksana (2008:259) bahwa wacana merupakan satuan bahasa terlengkap, dalam hierarki gramatikal merupakan satuan gramatikal tertinggi atau terbesar

Penggunaan bahasa, baik bahasa Indonesia maupun bahasa Jawa, kata, frasa, dan kalimatnya memiliki kesatuan yang bermakna dalam suatu teks. Sebuah teks tidak dapat berdiri sendiri, melainkan sesuatu yang saling berkaitan dan berhubungan. Secara nyata sebuah kata, frasa, dan kalimat dalam teks tersebut akan lebih bermakna jika terdapat hubungan satu dengan yang lain. Salah satu peranan untuk keutuhan sebuah wacana digunakan kata sambung/konjungsi di dalam kalimat. Kridalaksana (2008:131) menyatakan bahwa konjungsi adalah partikel yang dipergunakan untuk menghubungkan kata dengan kata, frasa dengan frasa, kalusa dengan klausa, kalimat dengan kalimat atau paragraf dengan paragraf.

Unsur yang dirangkai dapat berupa satuan lingual kata, frasa, kalimat, dan dapat juga berupa unsur yang lebih besar dari itu, misalnya alinea dengan pemarkah lanjutan, dan topik pembicaraan dengan pemarkah alih topik atau pemarkah disjungtif. Tanpa konjungsi, komunikasi akan terputus-putus dan tidak mengalir dengan lancar sehingga dapat menimbulkan hambatan-hambatan dalam berkomunikasi.

Dalam bidang bahasa yang menggunakan wacana tulis di antaranya adalah surat kabar, buku, artikel, majalah dan lain sebagainya. Maka, penelitian ini akan fokus pada konjungsi antarkalimat dan konjungsi antarparagraf dalam wacana media tulis online tajuk rencana Suara Merdeka.com, buku ajar Buku Sekolah Elektronik (BSE), dan artikel ilmiah populer karena peneliti menduga bahwa pemakaian konjungsi antarkalimat dan antarparagraf dapat ditemukan dalam wacana-wacana tersebut. Pemakaian konjungsi digunakan sebagai penghubung unsur yang satu dengan unsur yang lain dalam wacana.

\section{METODE PENELITIAN}

Pendekatan yang digunakan pada penelitian ini adalah pendekatan teoretis dan pendekatan metodologis.Pendekatan teoretis yang digunakan di dalam penelitian ini adalah pendekatan analisis wacana. Adapun pendekatan metodologis yang digunakan dalam penelitian ini adalah pendekatan kualitatif yang bersifat deskriptif. Pendekatan kualitatif digunakan dalam penelitian ini karena merupakan prosedur penelitian yang menghasilkan data deskriptif berupa kata-kata tertulis atau lisan tentang individu, keadaan, gejala dari kelompok tertentu yang dapat diamati, pendapat tersebut menurut Bogdan dan Taylor (dalam Moleong, 2009:4).

Data dalam penelitian ini berupa penggalan wacana yang terdapat pada wacana tajuk rencana online Suara Merdeka.com edisi bulan Juni 2016 sampai dengan Juli 2016, buku ajar BSE Bahasa dan Sastra Indonesia SMP sampai dengan SMA terbitan Pusat Perbukuan Departemen Pendidikan Nasional, dan artikel ilmiah populer yang diakses dalam link https://parapenuliskreatif.wordpres.com/catego 
ry/artikel-ilmiah-populer/page/4/ yang diduga mengandung konjungsi. Sumber data dalam penelitian ini berupa wacana yang terdapat pada tajuk rencana online Suara Merdeka.com, buku ajar BSE Bahasa dan Sastra Indonesia, dan artikel ilmiah populer.

Metode pengumpulan data dalam penelitian ini, menggunakan metode simak yang dilakukan dengan cara menyimak penggalan wacana. Menurut Sudaryanto (1993:132) metode simak adalah metode yang digunakan dalam penelitian bahasa dengan cara menyimak penggunaan bahasa pada objek yang akan diteliti. Metode simak dipilih peneliti karena objek yang diteliti berupa bahasa yang sifatnya teks. Metode simak kemudian dilanjutkan dengan teknik catat yang berarti peneliti mencatat data yang dinilai tepat dalam kajian analisis konjungsi wacana pada sebuah kartu data.

Metode yang digunakan dalam analisis ini adalah metode agih. Metode agih disebut juga metode distribusional (Sudaryanto dalam Kesuma 2007:54) adalah metode analisis yang alat penentunya ada di dalam dan merupakan bagian dari bahasa yang diteliti. Metode agih dilanjtkan dengan teknik baca markah. Teknik baca markah menurut Sudaryanto (1993:95) disebut juga teknik membaca pemarkah. Pemarkah itu adalah alat seperti imbuhan, kata penghubung, kata depan, dan artikel yang menyatakan ciri ketatabahasaan atau fungsi kata atau kontruksi (Kridalaksana dalam Kesuma 2007:66). Metode penyajian hasil analisis data yang digunakan dalam penelitian ini adalah metode informal.

\section{HASIL PENELITIAN DAN PEMBAHASAN}

Konjungsi adalah salah satu jenis kohesi gramatikal yang dilakukan dengan cara menghubungkan unsur yang satu dengan unsur yang lain dalam wacana. Berdasarkan rumusan masalah dan tujuan penelitian, dikemukakan hasil penelitian dan pembahasan tentang konjungsi wacana antarkalimat dan konjungsi wacana antarparagraf. Hasil analisisnya adalah (1) konjungsi antarkalimat yang terdapat dalam wacana tajuk rencana online Suara Merdeka, buku BSE Bahasa dan Sastra Indonesia, dan artikel ilmiah populer dan, (2) konjungsi antarkalimat yang terdapat dalam wacana tajuk rencana online Suara Merdeka, buku BSE Bahasa dan Sastra Indonesia, dan artikel ilmiah populer. Media tulis (online), buku teks (pelajaran), dan artikel ilmiah populer yang menjadi objek penelitian ini adalah wacana tajuk rencana online Suara Merdeka.com edisi bulan Juni 2016 sampai dengan Juli 2016, buku ajar BSE Bahasa dan Sastra Indonesia SMP sampai dengan SMA terbitan Pusat Perbukuan Departemen Pendidikan Nasional, artikel ilmiah populer yang diakses dalam link https://parapenuliskreatif.wordpres.com/catego ry/artikel-ilmiah-populer/page/4/.

\section{Kohesi Konjungsi Antarkalimat}

Kohesi konjungsi antarkalimat adalah kata hubung yang menghubungkan antara satu kalimat dengan kalimat yang lain sehingga kalimat menjadi logis. Berdasarkan hubungan gramatik antara kalimat-kalimat yang menjadi unsurnya, (Ekowardono 1985:49) membedakan kohesi konjungsi antarkalimat menjadi dua, yaitu konjungsi koordinatif dan konjungsi subordinatif.

\section{Pemarkah Konjungsi Koordinatif}

Konjungsi koordinatif adalah konjungsi yang digunakan sebagai penghubung antarkalimat dalam paragraf dan kedua kalimat itu memiliki status sintaksis yang sama. Konjungsi antarkalimat koordinatif terdiri atas 1) konjungsi alternatif, 2) konjungsi balikan, 3) konjungsi dubitatif, 4) konjungsi kontrastif, 5) konjungsi serempakan, 6) konjungsi simpulan, 7) konjungsi tak sesuaian, dan 8) konjungsi urutan. Berikut adalah salah satu contoh analisis dari 234 data yang diperoleh.

\section{(1) Konjungsi Simpulan}

Konjungsi yang digunakan sebagai pemarkah kohesi adalah jadi, maka, pendeknya, singkatnya. Dari 234 data yang dianalisis terdapat konjungsi simpulan jadi sebanyak 17 data, maka sebanyak 12 data, pendeknya sebanyak 1 data, dan singkatnya sebanyak 1 
data. Berikut contoh dan analisis wacana yang mengandung konjungsi antarkalimat pemarkah konjungsi koordinatif simpulan jadi, maka, pendeknya, singkatnya.

a. Padahal Indonesia boleh dibilang baru saja menerapkan kebijakan semacam pada 2008 lewat sunset policy. Jadi, ada baiknya pemerintah mengantisipasi kemungkinan bolong-bolong pelaksanaan pengampunan pajak, baik melalui aturan turunan maupun sosialisasi masif.

(Data 192/SM 15Juli 2016)

b. Biasanya seperti club malam yang selalu menyediakan minuman seperti yang di maksud di atas. Maka tidak mengherankan lagi jika banyak kejadian - kejadian buruk yang ada disana.

(Dtaa 145/AIP Bahaya Minuman Beralkohol Terhadap Kesehatan)

c. Hilang rona karena penyakit, hilang bangsa karena tak beruang - tak ada salahnya dan janggallah jika pepatah itu ditambah sekarang dengan: hilang bangsa dan negeri karena tiada berpengetahuan. Pendeknya, ilmu pengetahuan itu terpandang dalam segala perkara.

(Data 154/BSE kelas IX hal.103-104)

d. Kadang-kadang ada yang aneh-aneh: ada yang gemar mendaki gunung, ada yan gemar memelihara hewan, ada yang gemar menonton film, bermain catur, dan mengumpulkan kartu telepon. Singkatnya, ada bermacam kegemaran orang yang biasa disebut hobi.

(Data 195/BSE kelas X hal.128)

Pada penggalan wacana (a), (b), (c), dan (d) terdiri atas dua kalimat yang menggunakan konjungsi antarkalimat, yaitu pemarkah konjungsi koordinatif simpulan. Kata penghubung jadi, maka, pendeknya, singkatnya yang bercetak tebal pada penggalan kalimat di atas merupakan kata penghubung antarkalimat yang menyatakan penyimpulan. Kalimat di atas dihubungkan dengan konjungsi simpulan yang menyebutkan inti persoalan kalimat-kalimat sebelumnya.

\section{Pemarkah Konjungsi Subordinatif}

Konjungsi subordinatif adalah konjungsi yang digunakan sebagai penghubung antarkalimat dalam paragraf, dan kalimatkalimat yang dihubungkan memiliki status sintaksis yang berbeda. Artinya, kalimat yang satu menjadi bagian atau menjelaskan kalimat yang lain. Konjungsi antarkalimat subordinatif terdiri atas: 1) konjungsi ekseptif, 2) konjungsi jelasan, 3) konjungsi konsesif, 4) konjungsi misalan, 5) konjungsi optatif, dan 6) konjungsi sebab akibat. Berikut adalah salah satu contoh analisis dari 234 data yang diperoleh.

\section{Konjungsi optatif}

Konjungsi yang digunakan sebagai pemarkah kohesi adalah mudah-mudahan, moga-moga, semoga. Dari 234 data yang dianalisis terdapat konjungsi optatif mudahmudahan sebanyak 3 data dan semoga sebanyak 4 data. Sementara konjungsi moga-moga dalam analisis ini tidak ditemukan. Berikut contoh dan analisis wacana yang mengandung konjungsi antarkalimat pemarkah konjungsi subordinatif optatif mudah-mudahan dan semoga

Bila bebanmu sudah terasa lebih ringan, berceritalah akan kudengarkan. Mudahmudahan aku bisa menolongmu.

(Data 101/BSE kelas VIII hal.119)

a. Kios itu ke kiri, terus sedikit dan nomornya sudah jelas. Semoga kita dapat bersua nanti dalam rumah tetangga saya itu yang selalu saya puji sebagai nenek dari Negeri Insulinde yang paling gracieus.

(Data 80/BSE kelas VII hal.82) 
Pada penggalan wacana (a) dan (b) terdiri atas dua kalimat yang menggunakan konjungsi antarkalimat, yaitu pemarkah konjungsi subordinatif optatif mudah-mudahan dan semoga. Kalimat di atas diawali konjungsi optatif yang menyatakan suatu harapan atau doa tentang sesuatu hal yang telah dinyatakan pada kalimat sebelumnya.

\section{Kohesi Konjungsi Antarparagraf}

Kohesi konjungsi antarparagraf adalah kata-kata penghubung yang menghubungkan antar paragraf. Konjungsi yang sering digunakan untuk pertalian antarparagraf dibedakan atas konjungsi koordinatif dan konjungsi subordinatif.

\section{Pemarkah Konjungsi Koordinatif}

Konjungsi antarparagraf koordinatif adalah konjungsi yang digunakan sebagai penghubung antarparagraf dalam wacana, dan paragraf-paragraf itu memiliki status sintaksis yang sama. Konjungsi antarparagraf koordinatif terdiri atas 1) konjungsi aditif, 2) konjungsi serempakan, 3) konjungsi simpulan, dan 4) konjungsi urutan. Berikut adalah salah satu contoh analisis dari 234 data yang diperoleh.

\section{Konjungsi Aditif}

Dalam hubungan aditif, pemarkah konjungsi yang digunakan adalah tambahan pula, lagi pula, selain itu. Dari 234 data yang dianalisis terdapat konjungsi aditif tambahan pula sebanyak 1 data, lagi pula sebanyak 1 data, dan selain itu sebanyak 2 data. Berikut contoh dan analisis wacana yang mengandung konjungsi antarparagraf pemarkah konjungsi koordinatif aditif tambahan pula, lagi pula, dan selain itu.

Sejauh ini, aparatur negara itu telah memperoleh berbagai tambahan kesejahteraan. Tujuan tambahan itu sudah pasti untuk meningkatkan kinerja, kreativitas, dan inovasi dalam berbagai bentuk layanan masyarakat dan tugas-tugas administratif. Misalnya gaji ke-13, gaji ke-14, tunjangan penghasilan pegawai, dan surat perjalanan dinas. a. Tambahan pula penghasilan ASN itu menjadi pembicaraan di instansi lain, misalnya pegawai pada badan usaha milik negara. Namun, keputusan telah dikuatkan dengan regulasi dengan harapan aparatur negara makin berkualitas.

(Data 204/SM 30 Juli 2016) ...Itulah yang menjadi duri dalam daging, yang selalu terasa-rasa oleh yang muda. Oleh sebab itu, acap kali ia tiada setia; berpaling hatinya kepada yang lain yang sebaya dengan dia. Yang tua itu pun terkadang-kadang tak senang pula hatinya; malu kepada orang, sebab jodoh yang sangat besar perbedaannya itu, tentulah menjadi buah tutur orang segenap negeri.

b. Lagi pula, orang yang telah tua itu berlainan pikiran, kemajuan, kesukaan, kelakuan, tabiat, adat, dan kepandaiannya dengan orang muda. Kemajuan yang tua, misalnya jangan terlalu banyak berjalan, karena kekuatannya tidak berapa lagi; tetapi yang muda itulah yang dikehendakinya, karena tak betah selalu di rumah.

(Data 141/BSE kelas IX hal.87)

....Beberapa manfaat dari akar wasabi di antaranya, dapat mengaktifkan antioksidan dalam tubuh dan meningkatkan daya tahan tubuh dari serangan bakteri, mengaktifkan fase enzim untuk proses detoksifikasi atau pengeluaran racun dalam tubuh, menangkal keracunan makanan yang disebabkan oleh mikroba, membersihkan organ hati sebagai pembentuk cairan empedu, menciptakan berbagai enzim pencernaan makanan, melindungi dari serangan kanker perut, kanker usus besar, dan kenker payudara, mengobati sakit gigi dengan mengurangi pertumbuhan bakteri yang menyebabkan lubang pada gigi, serta membantu proses pembekuan darah.

c. Selain itu wasabi juga berkhasiat sebagai perangsang hasrat seksual bagi laki-laki. Penggunaan wasabi tidak hanya dengan dimakan, namun juga bisa diaplikasikan langsung pada kulit. Wasabi yang dapat mengaktifkan 
antioksidan dapat melindungi dan mengobati kulit dari radikal bebas.

\section{(Data 178/AIP Wasabi, Si Pedas yang Berkhasiat)}

Penggalan wacana (a), (b), dan (c) terdiri atas dua paragraf yang menggunakan konjungsi antarparagraf, yaitu pemarkah konjungsi koordinatif aditif. Kata penghubung tambahan pula, lagi pula dan selain itu yang bercetak tebal pada penggalan paragraf di atas merupakan kata penghubung antarparagraf yang menyatakan penegasan. Paragraf di atas diawali konjungsi aditif yang berisi keterangan tambahan pada paragraf sebelumnya.

\section{Pemarkah Konjungsi Subordinatif}

Konjungsi antarparagraf subordinatif adalah konjungsi yang digunakan sebagai penghubung antarparagraf dalam wacana, dan paragraf-paragraf itu memiliki status sintaksis yang berbeda. Artinya, paragraf yang diawali dengan konjungsi subordinatif menjadi bagian atau menjelaskan paragraf sebelumnya. Jenis konjungsi antarparagraf subordinatif meliputi 1) konjungsi jelasan, 2) konjungsi misalan, 3) konjungsi optatif, 4) konjungsi rangkuman, dan 5) konjungsi sebab akibat. Berikut adalah salah satu contoh analisis dari 234 data yang diperoleh.

\section{Konjungsi Jelasan}

Konjungsi yang digunakan sebagai pemarkah kohesi adalah dengan kata lain, paragraf yang diawali konjungsi jelasan berisi penjelasan paragraf sebelumnya. Dari 234 data yang dianalisis terdapat konjungsi jelasan dengan kata lain sebanyak 1 data. Berikut contoh dan analisis wacana yang mengandung konjungsi antarparagraf pemarkah konjungsi koordinatif jelasan dengan kata lain.

Berdasarkan kemempuan otak, cara belajar individu dapat dibagi dalam tiga kategori. Ketiga kategori itu cara belajar visual, auditorial, dan karakteristik yang ditandai dengan ciri-ciri perilaku tertentu. Pengategorian ini tidak berarti, individu hanya yang memiliki salah satu karakteristik cara belajar tertentu sehingga tidak memiliki karakteristik cara belajar yang lain.

Dengan kata lain, jika sang individu menemukan metode belajar sesuai karakteristik dirinya, akan cepat ia menjadi "pintar". Dengan demikian, kursus atau les privat intensif tidak diperlukan lagi.

(Data 127/BSE kelas XI hal.12)

Penggalan wacana (a) terdiri atas dua paragraf yang menggunakan konjungsi antarparagraf, yaitu pemarkah konjungsi subordinatif jelasan dengan kata lain. Paragraf di atas diawali konjungsi jelasan yang berisi penjelasan pada paragraf sebelumnya.

\section{SIMPULAN}

Berdasarkan penelitian yang dilakukan penulis dapat diambil beberapa simpulan sebagai berikut.

Konjungsi kohesi antarkalimat koordinatif meliputi 1) konjungsi alternatif jika (29), tidak (20), kalau tidak (1), 2) konjungsi balikan sebaliknya (6), 3) konjungsi dubitatif jangan-jangan (2), 4) konjungsi kontrastif akan tetapi (7), 5) konjungsi serempakan sementara itu (6), 6) konjungsi simpulan jadi (17), maka (12), pendeknya (1), singkatnya (1), 7) konjungsi taksesuaian padahal (15), 8) konjungsi urutan lalu (10), kemudian (10), akhirnya (1), serta konjungsi kohesi antarkalimat subordinatif meliputi 1) konjungsi ekseptif kecuali (1), 2) konjungsi jelasan maksudnya (2), artinya (7), dengan kata lain (1), adapun (1), 3) konjungsi konsesif walaupun (5), 4) konjungsi misalan misalnya (12), 5) konjungsi optatif mudahmudahan (3), semoga (4), 6) konjungsi sebab akibat karena itu (1), walaupun demikian (1), malahan (1), bahkan (21).

Konjungsi kohesi antarparagraf koordinatif meliputi 1) konjungsi aditif tambah pula (1), lagi pula (1), selain itu (2), 2) konjungsi serempakan sementara itu (8), 3) konjungsi simpulan dengan demikian (1), jadi (1), maka (2), 4) konjungsi urutan mula-mula (1), selanjutnya (1), kemudian (1), akhirnya (6), serta kohesi konjungsi antarparagraf subordinatif meliputi 1) konjungsi jelasan dengan kata lain (1), 2) konjungsi misalan misalnya (3), sebagai contoh (1), 
3) konjungsi optatif mudah-mudahan (1), 4) konjungsi rangkuman pendeknya (1), 5) konjungsi sebab akibat oleh karena itu (2), walaupun demikian (1), meskipun demikian (1).

\section{DAFTAR PUSTAKA}

Ekowardono, B. Karno. 1985. Paragraf: Pengertian Dasar, Aspek Semantis, Leksikal, dan Gramatikal. Diktat. Semarang: FPBS IKIP Semarang.

Kesuma, Tri Mastoyo Jati. 2007. Pengantar (Metode) Penelitian Bahasa. Yogyakarta: Carasvati Books.

Kridalaksana, Harimurti. 2008. Kamus Linguistik. Jakarta: Gramedia Pustaka Utama.

Moleong, Lexy. 2009. Metode Penelitian Kualitatif. Bandung: PT Remaja Rosdakarya.

Sudaryanto. 1993. Metode dan Aneka Teknik Analisis Bahasa.Yogyakarta: Duta Wacana University Press.

Sudaryanto. 1993. Metode dan Aneka Teknik Analisis Bahasa. Yogyakarta: Duta Wacana University Press. 